\title{
Penggunaan Bahasa Jurnalistik dalam Penulisan Berita Metrojambi.Com
}

\author{
Febrina Ita Fitri Anti, Agus Salim, Jamaluddin Arsyad \\ UIN Sulthan Thaha Saifuddin Jambi \\ Email: jamaluddinarsyad@uinjambi.ac.id
}

\begin{abstract}
Abstrak: Penerapan bahasa jurnalistik pada media pemberitaan adalah suatu keharusan. Berita yang baik adalah berita yang menggunakan bahasa yang sederhana dan mudah diterima logika pembaca. Namun tidak semua pihak yang terlibat dalam produksi berita memahami pentingnya penggunaan bahasa jurnalistik pada penulisan berita di media massa, termasuk wartawan dan editor di MetroJambi.com dimana penelitian dilakukan. Sebagai media daring terbaik tahun 2016 di Jambi, MetroJambi.com masih memuat kesalahan bahasa pada berita-beritanya. Tujuan penelitian ini adalah (1) Untuk mengetahui profil dan latar belakang kelahiran portal berita metrojambi.com (2) meneliti penggunaan bahasa jurnalistik pada portal berita metrojambi.com (3) mengkaji upaya yang dilakukan Metrojambi.com dalam mengatasi kesalahan penggunaan bahasa jurnalistik pada media tersebut. Metode penelitian yang penulis gunakan kualitatif dengan pendekatan kajian kandungan berita. Teknik pengumpulan data dilakukan melalui dua cara, pertama mewawancarai editor Metrojambi.com, General Manajer metrojambi.com, dan Kepala Kantor Bahasa Jambi, serta tiga orang Penyuluh Kantor Bahasa Jambi. Kedua, melakukan pengumpulan berita dari tanggal 01 September 2019 sampai tanggal 09 September 2019 yang kemudian dianalisis dan dideskripsi dalam penelitian ini. Hasilnya peneliti menemukan yaitu: pertama Metrojambi.com berasal dari media cetak Metro Jambi, kedua terdapat 7 kesalahan penggunaan bahasa jurnalistik dalam penulisan berita di Metrojambi.com dari 01 September 2019 sampai tanggal 09 September 2019. Hal ini yang nampaknya menjadikan Metrojambi.com tidak lagi masuk pada kategori media terbaik di Provinsi Jambi pada tahun 2019, ketiga editor dan general manager Metrojambi.com memberikan pelatihan kepada para wartawan mengenai peliputan dan penulisan, selalu mengikutsertakan para wartawan dalam kegiatan pelatihan dam penyuluhan yang diselenggarakan oleh organisasi AJI, Kantor Bahasa Jambi dan segala yang berhubungan dengan kegiatan wartawan, serta editor Metrojambi.com juga melakukan penelitian yang lebih teliti lagi dari sebelumnya, supaya meminimalisir kesalahan penulisan pada berita. Penelitian merekomendasikan kepada Metrojambi.com untuk dapat memperhatikan penggunaan bahasa Jurnalistik pada berita-berita yang dipublikasikan, serta memberikan pemahaman kepada para wartawan tentang tatacara penulisan berita yang sesuai dengan bahasa jurnalistik yang baik dan benar.

Kata-kata kunci: bahasa jurnalistik, Metrojambi.com.
\end{abstract}




\section{A. Pendahuluan}

Ciri utama bahasa jurnalistik yaitu sederhana, singkat, padat, lugas, jelas, jernih, menarik, demokratis, mengutamakan kalimat aktif, sedapat mungkin tidak menggunakan kata atau istilah-istilah teknis, dan tunduk kepada kaidah serta etika bahasa baku. ${ }^{1}$ Penulisan berita harus sesuai dengan kalimat atau bahasa baku agar mudah dipahami oleh masyarakat. Seorang jurnalis harus tunduk pada kaidah bahasa jurnalistik, karena bahasa jurnalistik yang baik selain mudah dipahami pembaca, juga bahasa yang mampu membuat perusahaan media massa diakui eksistensinya. Kesalahan dalam bahasa juga mampu berakibat fatal, seperti berkurangnya pemahaman pembaca mengenai bahasa baku, serta kesalahan penulisan mampu mengakibatkan kesalahan pemahaman antara pesan yang disampaikan penulis dengan pembaca. Seperti kasus pesan yang memiliki makna ganda.

"kami juga tambah ikhsanudin melakukan tugas pembinaan territorial kerjasama dengan kodim, Pemerintah, stakholder dan lintas sektor. "Mudah-mudahan keberadaan kami disini bisa membantu Pemerintah Daerah dan seluruh masyarakat Belu. Karena disini juga bagian dari NKRI dimana kita saling jaga keutuhan NKRI," ucap dia." ${ }^{2}$

Hal ini memiliki makna yang berbeda dengan pesan yang ingin di sampaikan oleh penulis. Kata "kami juga tambah ikhsanudin melakukan tugas pembinaan territorial kerjasama dengan kodim, Pemerintah, stakholder dan lintas sektor" memiliki makna bahwa beberapa orang bersama ikhsanudin melakukan pembinaan territorial kerjasama, atau kami juga menambahkan bahwa Ikhsanuddin melakukan tugas pembinaan kerjasama dengan kodim, Pemerintah stakholder dan lintas sektor. Oleh karena itu bahasa jurnalistik harus diterapkan dengan baik, karena bahasa jurnalistik akan membuat pembaca mampu memahami makna dari isi berita. Serta penggunaan bahasa yang baik dan benar akan membuat para pembaca tanpa disadari memahami bahasa baku yang sesuai dengan Pedoman Umum Ejaan Bahasa Indonesia (PUEBI), serta mampu menjadi tempat pembelajaran dalam berbahasa.

${ }^{1}$ Haris Sumadiria, Jurnalistik Indonesia Menulis Berita dan Ferature Cetakan Keempat (Bandung: Simbiosa Rekatama Media, 2011), 53

${ }^{2}$ Ikbal Ferdiyal, "Yonif Raider 142/Ksatria Jaya Jaga Perbatasan RI RDTL Sektor Timur" diakses melalui https://www.metrojambi.coom/read/2019/09/11/46946/yonif-raider-142ksatriajaya-jaga-perbatasan-rirdtl-sektor-tiłmur, tanggal 14 April 2020 
Menurut Kamus Besar Bahasa Indonesia atau disingkat KBBI, Bahasa merupakan sistem bunyi yang digunakan oleh masyarakat untuk bekerja sama, berinteraksi, dan mengidentifikasikan diri. Bahasa jurnalistik juga adalah bahasa pers, yaitu bahasa yang digunakan jurnalis dalam menulis berita untuk media cetak dan daring, yang harus mengandung unsur lima pertanyaan: apa, siapa, dimana, kapan, mengapa dan bagaimana $(5 \mathrm{~W}+1 \mathrm{H})$. Seorang wartawan akan menggunakan bahasa baku yang baik dan benar yaitu yang sesuai dengan EYD. ${ }^{3}$

Metro Jambi merupakan media cetak yang berada di Kota Jambi dan telah menjadi portal digital atau media daring sejak Oktober 2010, serta meraih prestasi sebagai media terbaik di provinsi Jambi pada 2016 versi Alexa.Com per/April 2016. ${ }^{4}$ Menurut Editor metrojambi.com (wawancara, pada Oktober 2019) bahasa jurnalistik telah diterapkan secara serius oleh dewan redaksi sejak lahirnya media ini. Kelahiran metrojambi.com untuk menunjang media cetak Pos Metro Jambi yang ada sejak 8 Oktober 2002, namun pada 6 Januari 2017 Pos Metro memisahkan diri menjadi perusahaan lokal dengan nama Metro Jambi, atau Harian Metro Jambi dan kemudian melahirkan metrojambi.com sebagai salah satu media daring di Jambi yang mengikuti dinamika transformasi pemberitaan dari konvensional ke media daring. ${ }^{5}$

Pada pertengahan tahun 1990-an, kemunculan internet memang telah memicu kelahiran media daring atau online di Indonesia. Meningkatnya jumlah portal berita online seiring perkembangan internet, membuat warga negara semakin mudah mengakses berita, khususnya bagi mereka yang memiliki ponsel atau smartphone yang

${ }^{3}$ Ni Wayan eviyanti Siska Pratiwi, "Kemampuan Siswa Kelas VII B SMP Negeri 1 Torue dalam Menulis Teks Berita", Jurnal Bahasa dan Sastra, Vol. 3, No 4 Tahun 2018

${ }^{4}$ Metro Jambi, "Tentang Kami," diakses melalui https://https://https://metrojambi.com/profil/tentang-kami/profil/tentang-kami/profil/tentang-kami, Tanggal 25 februari 2020

Metro Jambi, "Tentang Kami”, diakses melalui alamat https://https://https://metroJambi.com/profil/tentang-kami/profil/tentang-kami/profil/tentang-kami, tanggal 12 Desember 2019 
terkoneksi internet. Profesi jurnalis online semakin populer. Namun, perhatian pembaca tetap terletak pada kualitas bahasa yang digunakan, baik pada media konvensional maupun media daring atau online tersebut. Kecepatan penulisan berita dan pengembangan berita real-time selalu menjadi tantangan sekaligus prioritas bagi media online. Arsenault dan Castells berpendapat bahwa internet adalah alat komunikasi massa karena memiliki potensi untuk menjangkau khalayak secara global. Namun internet juga bisa menjadi komunikasi pribadi, karena setiap individu diberi kesempatan untuk membuat konten pribadi, memilih media penyebarannya, serta bisa berperan aktif dalam membentuk proses penerimaannya. ${ }^{6}$

Metro Jambi sejak berdiri, menurut Editornya, berusaha memberikan informasi terbaik bagi penerima atau penggunanya dengan sedapat mungkin mengemukakan bahasa jurnalistik yang baik. ${ }^{7}$ Penyebaran informasi oleh seorang jurnalis Metro Jambi, sebagaimana kaidah umum jurnalisme, berusaha terikat oleh bahasa jurnalistik yang menjadi kaidah-kaidah penulisan dalam pemberitaan. Bahasa jurnalistik bisa dipahami sebagai bahasa komunikatif ${ }^{8}$ Yang kadang disebut sebagai bahasa pers, dan merupakan salah satu variasi bahasa yang berpedoman pada bahasa Indonesia. Bahasa jurnalistik tetap terikat pada sifat, adat, dan kaidah bahasa baku, baik kata bahasanya, istilah, maupun ejaan. ${ }^{9}$

Pada proses menyampaikan informasi dan menerima informasi, bahasa jurnalistik memiliki peran penting dalam memudahkan pemahaman maksud dari informasi yang disampaikan. Pada perusahaan media, yaitu sebuah perusahaan pemberitaan yang memberikan informasi seputar peristiwa yang terjadi sehari-hari, pemberitaan dengan bahasa yang baik harus dilakukan setiap hari. Dengan bahasa yang baik, media massa bisa memberikan informasi yang dapat dipahami oleh publik. Seorang jurnalis yang bekerja untuk sebuah media, akan memberikan informasi kepada publik, dalam menyampaikan informasi, seorang jurnalis akan memperhatikan tulisan yang ingin disebarkan.

${ }^{6}$ Yanuar Nugroho et. Al., Memetakan Lansekap Industri Media Kontemporer di Indonesia (Jakarta: Centre for Innovation Policy and Governance, 2012), 87

${ }^{7}$ Wawancara dengan Editor Metro Jambi

${ }^{8}$ Abdul Chaer, Bahasa Jurnalistik (Jakarta: PT. Rineka Cipta, 2010), 4

${ }^{9}$ Maskun Iskandar dan Atmakusumah, Panduan Jurnalistik Praktis, Mendalami Penulisan Berita dan Feature, Memahami Etika dan Hukum Pers, Cetakan Kelima (Jakarta: Lembaga Pers Dr. Soetomo (LPDS), 2012), 283 
Era media pemberitaan daring saat ini, tidak sedikit media massa yang melakukan kesalahan-kesalahan dalam penulisan berita. Sebagaimana yang dijelaskan JS. Badudu yang dikutip oleh Abdul Chaer dalam bukunya 'Bahasa Jurnalistik', Abdul mengatakan kesalahan yang dilakukan oleh pihak jurnalis antara lain: penggunaan ejaan, pemilihan kata, penghilangan unsur-unsur gramatikal, dan penyusunan kalimat-kalimat yang kurang tepat. ${ }^{10}$

Pada era globalisasi saat ini, perkembangan teknologi informasi semakin canggih, hampir setiap waktu masyarakat bisa memperoleh informasi, baik melalui surat kabar, majalah, radio, televisi hingga internet. Perkembangan teknologi informasi dan meluasnya jaringan internet di seluruh penjuruh dunia, memberikan kemudahan bagi masyarakat untuk mendapatkan informasi dan memberikan informasi.

Media massa adalah salah satu penyebaran informasi nomor satu di dunia, begitu banyak informasi yang beredar di media massa. Salah satu cara memperoleh informasi yang ada di media massa yaitu dengan membaca. Media massa akan membuat pembaca untuk lebih tertarik lagi dengan membaca, sehingga pembaca akan memperoleh informasi setiap hari. Pemberitaan yang melalui media mampu menyampaikan opini publik secara berkesinambungan, tidak sedikit pula ideologi masyarakat semakin terbentuk kokoh karena arus media massa yang gencar menyuarakan berbagai peristiwa, pendapat dan pemikiran narasumber.

Media atau pers yaitu salah satu cara menyebarkan dan memperoleh informasi yang dibutuhkan. Hadirnya media massa untuk membantu masyarakat dalam memperoleh informasi dengan mudah, baik melalui surat kabar, televisi dan media online. Media massa banyak dimanfaati oleh masyarakat dan media media yang ada.

Asep Syamsul M. Romli dalam buku Jurnalistik Online: Panduan Mengelola Media Online (Nuansa, Bandung, 2012) mengartikan media online sebagai berikut: media online (online media) adalah media massa yang tersaji secara online disitus web (website) internet. Lanjutnya, Romli juga menjelaskan dalam buku tersebut, media online adalah media massa "generasi ketiga" setelah media cetak (printed media) Koran,

${ }^{10}$ Abdul chaer, Bahasa Jurnalistik (Jakarta: PT. Rineka Cipta, 2010), 5 
tabloid, majalah, buku dan media elektronik (electronic media) radio, televisi dan film/ Video. ${ }^{11}$

Perkembangan zaman diiringi dengan perkembangan media masa yang ada. Informasi yang didapat juga begitu banyak, sehingga sulit untuk membedakan informasi yang benar dan informasi yang salah. Media online yang menjadi salah satu media yang memberikan kemudahan bagi para pemburu informasi untuk memperoleh informasi tanpa harus berpindah tempat. ${ }^{12}$ Saat ini telah banyak media yang berdiri di Indonesia, dan di provinsi Jambi khususnya, sehingga persaingan antar media semakin ketat. Provinsi Jambi merupakan salah satu provinsi terkecil di Indonesia. Meskipun termasuk provinsi terkecil, Jambi juga memiliki media pemberitaan yang tidak sedikit, sepert: TVRI, Jambi TV, Metro Jambi, Jambi Independent, RRI Jambi, Jambi Expres, Harian Jambi, Jambi One, dan Tribun Jambi.

Penyebaran informasi yang dilakukan Metro Jambi menggunakan dua cara, yaitu melalui media cetak dan media online. Pada media Koran disebut sebagai Harian Pagi Metro Jambi, sedangkan untuk online link nya Metrojambi.com, salah satu media online yang berada di bawah naungan Metro Jambi, salah satu media yang berhasil memperoleh penghargaan media nomor satu di provinsi Jambi. Dalam menyebarkan informasi, Metrojambi.com menggunakan tulisan dan gambar. Metrojambi.com memiliki beberapa kategori pembahasan, yaitu: Metro, Daerah, Politik, Hukum, Bisnis, Edukasi, Nasional, Dunia, Kisah, dan Gemaung, Untuk memfokuskan penelitian ini, peneliti hanya akan meneliti penulisan kategori Metro pada desember 2019 hingga Janusri 2020. Metrojambi.com adalah portal berita digital yang telah online sejak Oktober 2010 dan berhasil menjadi peringkat pertama Jambi, rangking 2,615 di Indonesia dan rangking 251,534 di dunia pada tahun 2016. Menurut versi Alexa.com Per/April 2016. ${ }^{13}$

Pengamatan awal yang peneliti lakukan, peneliti menemukan kesalahan dalam penulisan pada bahasa jurnalistik di portal Metrojambi.com, seperti logika bahasa atau

11 Asep Syamsul, M Romli. Jurnalistik Online: Panduan Mengelola Media Online (Nuansa: Bandung, 2012)

12 Mutiara Hatika, "Strategi Pemberitaan (LKBN) Antara Biro RIAU Dalam Menghadapi Persaingan Dengan Media Online" JOM FISIP Vol. 5 No. 1 - April (2018), 5.

13 Metro Jambi, "Tentang Kami", diakses melalui https://https://https://metroJambi.com/profil/tentang-kami/profil/tentang-kami/profil/tentang-kami, tanggal 12 Desember 2019 
pemilihan kata yang tidak tepat, pemborosan kata, kesalahan pengetikan, kesalahan membuat kalimat judul, kesalahan membuat kalimat pada isi berita, dan huruf yang berlebih.Wartawan dan Editor nampaknya tidak menyadari kesalahan ini. Selain itu, pada berita yang disebarkan juga terdapat logika berbahasa yang kurang tepat, seperti berita berjudul "Fachrori: Jadikan Peringatan 1 Muharram Wahana Evaluasi dan Introspeksi Diri". Kalimat judul ini salah satu contoh kalimat yang menggunakan logika berbahasa kurang tepat, sambungan kata dari 1 Muharram ke wahana akan menimbulkan berbagai macam arti, salah satunya 1 Muharram wahana atau 1 muharram sebagai wahana evaluasi dan introspeksi diri. Hal ini terkadang disadari oleh penulis atau wartawan media ini, namun mereka tetap menggunakannya. ${ }^{14} \mathrm{Hal}$ ini menjadi menjadi perhatian penulis untuk meneliti hal tersebut, karena akan berdampak buruk bagi masyarakat jika terus menerus menerima informasi yang dalam penulisannya tidak sesuai dengan pedoman.

\section{B. Penggunaan Bahasa Jurnalistik dalam Penulisan Berita Metrojambi.com}

Bahasa menurut Kamus Besar Bahasa Indonesia (KBBI) adalah sistem lambang bunyi yang arbitrer, yang digunakan oleh anggota suatu masyarakat untuk bekerja sama, berinteraksi dan mengidentifikasikan diri. ${ }^{15}$ Bahasa jurnalistik merupakan jenis bahasa yang masih terpaku pada bahasa Indonesia, bahasa jurnalistik biasa dikatakan sebagai bahasa pers, yaitu bahasa yang digunakan pada penulisan berita yang digunakan pada media massa.

Berita (news) merupakan sajian utama sebuah media Massa di samping views (opini). Mecari bahan berita lalu menyusunnya merupakan tugas pokok wartawan dan bagian redaksi sebuah penerbitan pers (media massa). ${ }^{16}$

Menurut Pauk De Massenner dalam buku Here's The News: Unesco Associate yang dikutip langsung oleh Haris Sumadiria, news atau berita adalah sebuah informasi

\footnotetext{
14 Metro Jambi, "Tentang Kami”, diakses melalui https://www.metrojambi.com/read/2019/09/01/46794/fachrori-jadikan-peringatan-1-muharramwahana-evaluasi-dan-intropeksi-diri/, tanggal 01 September 2019

15 KBBI daring. Diakses melalui https://www.google.com/amp/s/kbbi.web.id/bahasa.html tanggal 14 Maret 2020

16 Rasyiid Ghaniy, Kesesuaian Penulisan Berita Tribun Online Jambi dengan Bahasa Jurnalistik, Skripsi (Fakultas Ushuluddin: Universitas Islam Negeri, 2017), 32
} 
yang penting dan menarik perhatian, serta minat khalayak pendengar, sedangkan menurut Charnley dan James M. Neal, berita adalah laporan tentang suatu peristiwa, opini, kecenderungan, situasi, kondisi, dan interpretasi yang penting, menarik, masih baru, dan harus secepatnya disampaikan kepada khalayak (Errol Jonathans dalam Mirza, 2000: 68-69).

Berdasarkan KBBI, berita adalah cerita atau keterangan mengenai kejadian atau peristiwa yang hangat atau berita yang sedang menjadi bahan perbincangan. ${ }^{17}$ Fokus utama di media dalam jaringan (daring) atau online adalah pada penulisan/teks berita. Oleh karena itu, setiap media harus memperhatikan penggunaan bahasan, yang meliputi ejaan, bentuk dan pilihan kata, serta kalimat aktif dan pasif. Setiap media yang menggunakan bentuk tulisan, pembaca akan sangat memperhatikan setiap tulisan yang disebarkan sehingga ketelitian dalam pengetikan, pengeditan, dan penyebaran harus sangat diperhatikan. Kesalahan sekecil apapun akan menjadi tolok ukur bagi pembaca dalam menilai sebuah media.

\section{Jenis-Jenis Berita Metrojambi.com}

Secara teknis atau secara fisik, media daring merupakan media massa yang berbasis telekomunikasi dan multimedia (komputer dan internet).

Metrojambi.com yang merupakan media massa daring hadir untuk mengembangkan media cetak Metro Jambi dan juga untuk memenuhi kebutuhan pembaca karena media yang berkembang begitu pesat membuat para pembaca koran semakin sedikit dan beralih ke media daring.

Metrojambi.com merupakan media daring jenis News Organisation Website, karena metrojambi.com merupakan lembaga pers yang menyediakan berita-berita yang aktual dan faktual dengan didukung oleh para wartawan yang telah diberikan pelatihan sebelum terjun ke lapangan.

Metrojambi.com memiliki beberapa jenis pemberitaan, yaitu: ${ }^{18}$

1. Metro

${ }^{17}$ KBBI daring, diakses melalui https://www.google.com/amp/s/kkbi.web.id tanggal 12 februari 2020

${ }^{18}$ Metro Jambi “Menu Metrojambi.com; kategori berita", diakses melalui metrojambi.com, tanggal 12 februari 2020 
Rubrik metro berisi tentang aktivitas pemerintah Provinsi Jambi dalam menjalankan tugasnya. ${ }^{19}$

2. Daerah,

Pemberitaan daerah berisi tentang harapan atau kegiatan tiap daerah yang berada di Provinsi Jambi, mulai dari tingkat desa hingga kabupaten. ${ }^{20}$

3. Politik

Rubrik politik merupakan sarana komunikasi dari pihak-pihak yang berkepentingan dengan suatu peristiwa perpolitikan. ${ }^{21}$

4. Hukum

Menurut KBBI, hukum adalah peraturan atau adat yang secara resmi dianggap mengikat, yang dibuat oleh penjabat negara yang terbentuk dalam undangundang. ${ }^{22}$ Pada merojambi.com, rubrik hukum membahas peraturan perundang-undangan, serta pelanggaran UU dan sanksi yang diberikan kepada yang melanggar

5. Bisnis

Pengertian bisnis dalam KBBI adalah usaha komersial dalam dunia perdagangan atau bidang usaha. Setiap pemberitaan bisnis menampilkan produk yang dikemas secara apik untuk menarik khalayak, seperti bisnis perumahan dengan menampilkan gambar rumah yang akan dijual. ${ }^{23}$

6. Nasional

Pemberitaan nasional membahas peristiwa yang terjadi di wilayah Indonesia. ${ }^{24}$

${ }^{19}$ Metro Jambi "Menu Metrojambi.com; kategori berita", diakses melalui metrojambi.com, tanggal 12 februari 2020

${ }^{20}$ Metro Jambi "Menu Metrojambi.com; kategori berita", diakses melalui metrojambi.com, tanggal 12 februari 2020

${ }^{21}$ Metro Jambi "Menu Metrojambi.com; kategori berita", diakses melalui metrojambi.com, tanggal 12 februari 2020 Juni 2020

${ }^{22}$ KBBI daring, diakses melalui https://www.google.com/amp/s/kkbi.web.id tanggal 03 Juni 2020

${ }^{23} \mathrm{KBBI}$ daring, diakses melalui https://www.google.com/amp/s/kkbi.web.id tanggal 03

${ }^{24}$ Metro Jambi "Menu Metrojambi.com; kategori berita", diakses melalui metrojambi.com, tanggal 12 februari 2020 
7. Dunia

Rubrik dunia berisi tentang kejadian di seluruh dunia, baik dalam negeri maupun luar negeri. ${ }^{25}$

8. Hiburan

Rubrik hiburan berisi tentang kabar yang menyenangkan atau bahagia, seperti akan diadakannya konser, pawai, dan lain-lain. ${ }^{26}$

9. Olahraga

Pemberitaan olahraga memuat kabar seputar olahraga.

10. Edukasi

Edukasi atau pendidikan merupakan rubrik yang dipandang penting bagi sebagian masyarakat karena pendidikan sebagai sarana pembelajaran untuk menggampai cita-cita. Segala bentuk informasi seputar pendidikan akan diberikan di pemberitaan edukasi. ${ }^{27}$

11. Kesehatan

Rubrik kesehatan berisi berita seputar dunia kesehatan. Beritanya diperoleh dari Dinas Kesehatan Provinsi Jambi dan jajarannya. Pemberitaan kesehatan akan memaparkan seputar peristiwa di dunia kesehatan. ${ }^{28}$

12. Teknologi

Rubrik teknologi banyak membahas seputar teknologi, seperti perkembangan teknologi di Indonesia dan negara tetangga, membahas akun, baik itu facebook, instagram, posel (email), maupun tiktok, serta membahas perkembangan kartu paket dan kartu perdana. ${ }^{29}$

${ }^{25}$ Metro Jambi "Menu Metrojambi.com; kategori berita", diakses melalui metrojambi.com, tanggal 12 februari 2020

${ }^{26}$ Metro Jambi "Menu Metrojambi.com; kategori berita", diakses melalui metrojambi.com, tanggal 12 februari 2020

${ }^{27}$ Metro Jambi "Menu Metrojambi.com; kategori berita", diakses melalui metrojambi.com, tanggal 12 februari 2020

${ }^{28}$ Metro Jambi "Menu Metrojambi.com; kategori berita", diakses melalui metrojambi.com, tanggal 12 februari 2020

${ }^{29}$ Metro Jambi "Menu Metrojambi.com; kategori berita", diakses melalui metrojambi.com, tanggal 12 februari 2020 
13. Otomotif

Otomotif berisi tentang pemberitaan seputar kendaraan bermotor. Rubrik otomotif juga memberitakan perlombaan yang menggunakan jasa otomotif dan penemuan-penemuan baru di bidang otomotif. ${ }^{30}$

14. Properti

Properti berisi tentang pemberitaan yang membahas segala bentuk properti, seperti desain rumah, model dapur, dan bedah rumah. ${ }^{31}$

15. Unik

Unik merupakan suatu hal yang langka dan penemuan baru, seperti pohon pisang yang memiliki jantung lebih dari satu, boneka barbie yang bisa mengaji. Keunikan ini akan menimbulkan minat masyarakat untuk membaca beritanya. ${ }^{32}$

16. Kolom

Kolom berita berisi tulisan berdasarkan opini jurnalis, seperti artikel dan tajuk rencana. Dengan demikian, kolom merupakan tulisan jurnalis yang diperoleh dari pemikirannya sehingga lebih mengedepankan opini daripada fakta. Hal ini kebalikan dari berita, yang pada umumnya lebih mengembangkan fakta daripada opini. ${ }^{33}$

17. Gaya

Rubrik gaya merupakan sebuah pemberitaan yang membahas busana (fashion), seperti gaya hijab, tutorial hijab terkini, busana syar'l terbaru, dan cara merawat helm agar tidak berjamur di musim hujan. ${ }^{34}$

\footnotetext{
${ }^{30}$ Metro Jambi "Menu Metrojambi.com; kategori berita", diakses melalui metrojambi.com, tanggal 12 februari 2020

${ }^{31}$ Metro Jambi "Menu Metrojambi.com; kategori berita", diakses melalui metrojambi.com, tanggal 12 februari 2020

${ }^{32}$ Metro Jambi "Menu Metrojambi.com; kategori berita", diakses melalui metrojambi.com, tanggal 12 februari 2020

${ }^{33}$ Metro Jambi "Menu Metrojambi.com; kategori berita", diakses melalui metrojambi.com, tanggal 12 februari 2020

${ }^{34}$ Metro Jambi "Menu Metrojambi.com; kategori berita", diakses melalui metrojambi.com, tanggal 12 februari 2020
} 


\section{Seremoni}

Seremoni menurut KBBI adalah yang bersifat upacara. Dalam pemberitaan di metrojambi.com, biasanya seremoni membahas upacara nasional, pelantikan pengurus negara, tuntutan negara, peresmian posyandu, dan lain-lain. ${ }^{35}$

19. PetroChina

PetroChina merupakan suatu perusahaan minyak dan gas (migas) yang berasal dari Tiongkok yang bergerak dari sektor energi. PetroChina sudah memiliki begitu banyak cabang di Indonesia. Salah satunya di wilayah Jambi, yaitu Tanjungjabung Timur. Pemberitaan PetroChina membahas seputar perkembangan migas dan segala sesuatu yang menyangkut perusahaan PetroChina. ${ }^{36}$

20. Kisah

Kisah menurut $\mathrm{KBBI}$ merupakan cerita tentang kejadian (riwayat dan sebagainya) dalam kehidupan seseorang dan sebagainya. Rubrik kisah mengangkat suatu peristiwa yang berasal dari masa lalu (sejarah), seperti berita tentang sejarah kota tua dan kapal kuno. ${ }^{37}$

21. Gemaung

Gemaung menurut KBBI adalah berkumandang. Namun, dalam rubrik ini maksud kata gemaung adalah angkat bicara atau menanggapi suatu peristiwa, seperti berita yang berjudul "Hendry Angkat Bicara, Terkait Video Seorang Wartawan di Jambi" yang diunggah pada 29 Oktober 2019. ${ }^{38}$

${ }^{35}$ KBBI daring, diakses melalui https://www.google.com/amp/s/kkbi.web.id tanggal 03 Juni 2020

${ }^{36}$ Metro Jambi "Menu Metrojambi.com; kategori berita", diakses melalui metrojambi.com, tanggal 12 februari 2020

${ }^{37}$ KBBI daring, diakses melalui https://www.google.com/amp/s/kkbi.web.id tanggal 03 Juni 2020

${ }^{38}$ KBBI daring, diakses melalui https://www.google.com/amp/s/kkbi.web.id tanggal 03 Juni 2020 


\section{Penggunaan Bahasa Jurnalistik Pada Penulisan Berita Metrojambi.com}

Bahasa jurnalistik adalah gaya bahasa yang digunakan wartawan dalam menulis berita. Bahasa jurnalistik bisa dikatakan sebagai bahasa komunikasi massa, yaitu bahasa yang merupakan cara berkomunikasi melalui media massa, baik secara lisan maupun tulisan. ${ }^{39}$ Penggunaan bahasa jurnalistik berbeda dengan penggunaan bahasa resmi, meskipun bahasa jurnalistik mengikuti kaidah bahasa baku. Namun, bahasa jurnalistik berbeda dengan bahasa sastra dan bahasa resmi. Menurut redaktur metrojambi.com, mereka telah menggunakan bahasa jurnalistik dengan sebaik-baiknya, sesuai dengan aturan bahasa yang berlaku.

Metrojambi.com merupakan media daring sehingga penyebaran informasi sangat cepat serta membuat penulis dan editor memiliki waktu yang singkat untuk menulis dan mengedit berita. Meskipun waktu yang terbilang singkat, wartawan harus tetap memperhatikan kaidah bahasa jurnalistik.

Penggunaan bahasa pada perusahaan pemberitaan merupakan suatu hal yang diharuskan karena dengan bahasa, penulis mampu menyampaikan pesan yang ingin disampaikan sehingga bahasa memiliki peran penting dalam penulisan berita. Bahasa membuat perusahaan diakui eksistensinya.

Menurut editor metrojambi.com, Ikbal Ferdiyal, perusahaan telah memberikan pemahaman tentang pemberitaan dan liputan melalui seminar pelatihan bagi para wartawan dan karyawan. Namun, dari hasil penelitian, peneliti menemukan penggunaan bahasa jurnalistik yang kurang tepat pada penulisan berita rubrik metro periode 1 hingga 9 September 2019.

Hal ini diakui Ikbal Ferdiyal dalam wawancara yang peneliti lakukan pada 10 Februari 2020. Beliau mengatakan bahwa dalam penulisan berita di metrojambi.com masih belum sempurna, masih terdapat kesalahan-kesalahan, seperti ejaan yang tidak tepat serta kata yang kurang dan salah ketik. Oleh karena itu, ada beberapa pembaca yang mengeluh. Kesalahan dalam pengetikan merupakan hal yang biasa dikarenakan berita daring mengejar waktu tayang yang cepat agar berita tersebut tidak ketinggalan.

39 Rahmah, Analisis Penerapan Bahasa Jurnalistik Terhadap Berita Kriminal Tribun Timur, "Skripsi” (Makassar: Universitas Islam Negeri Alauddin Makassar, 2016) h. 2 
Dari hasil wawancara tersebut sangat jelas penggunaan bahasa yang kurang tepat akan membuat pembaca merasa tidak nyaman dan berpikir keras untuk memahami maksud dari berita yang disampaikan. Kesalahan-kesalahan seperti ini seharusnya tidak perlu terjadi karena pembaca dapat salah menafsir maksud dari pemberitaan tersebut.

Metrojambi.com sebagai media daring yang penyajian informasinya sangat cepat dan keterlambatan dalam menyebarkan informasi akan membuat berita tidak dibaca oleh publik tetap harus memperhatikan kaidah bahasa. Percuma berita cepat turun jika pembaca merasa tidak nyaman saat membacanya. Akibatnya, media akan dipandang buruk di mata pembaca.

Setelah peneliti melakukan analisis di laman metrojambi.com dan wawancara pada pimpinan redaksi dan editor terdapat 70 kesalahan dari 80 berita yang terkait penggunaan bahasa yang tidak sesuai dengan bahasa jurnalistik.

\section{Upaya Yang Dilakukan Mengatasi Kesalahan Bahasa Jurnalistik}

Pada metrojambi.com terdapat 2 editor dan 2 general manager yang bertanggung jawab penuh terhadap berita-berita yang diterbitkan. Setiap berita yang akan disebarkan akan melalui yang nama penyuntingan yang dilakukan oleh editor, dan general manager sebagai kepala diseluruh bagian fungsional dalam sebuah perusahaan atau organisasi, maka general manager bertanggung jawab kepada seluruh bagian disuatu perusahaan atau organisasi.

Hasil observasi yang penelitian lakukan, metrojambi.com memiliki beberapa kesalahan dalam penulisan berita yang tidak sesuai dengan bahasa jurnalistik yang berpedoman pada bahasa Indonesia yang baik dan benar.

1. Editor

Dalam penyajian berita aka nada editor atau redaktur yang bertugas menyunting berita sebelum disebarkan. Metrojambi.com memiliki 2 editor yang bekerja untuk memberikan tulisan yang terbaik kepada publik. Sebagai seorang editor harus sering berkomunikasi kepada wartawan dan memberikan saran agar terjalinnya komunikasi yang baik. Adapun kendala yang sering dihadapi oleh editor dalam mengedit atau menyunting berita adalah

a. waktu, karena waktu keterlambatan dalam mempublikasikan berita akan membuat berita pada media metrojambi.com berkurang, karena masyarakat/ 
publik telah memperoleh berita dari media lain.selain itu ketelitian juga semakin berkurang karena yang difikirkan hanya cepat terbit. ${ }^{40}$

b. Tekanan, tekanan yang dialami editor dalam mengedit berita seperti Pemahaman wartawan dalam penulisan bahasa jurnalistik, serta tulisan wartawan yang banyak kesalahan membuat editor harus bekerjakeras dalam mengedit berita, selain itu editor juga harus secepat mungkin menyelesaikan editannya, sehingga ketelitian dalam pengeditan menjadi berkurang. ${ }^{41}$

2. General manager

General manajer yang memiliki tanggungjawab kepada seluruh bagian/fungsional pada suatu perusahaan atau organisasi, mengambil keputusan serta bertanggungjawab tercapai atau tidaknya tujuan perusahaan sera sebagai pengendali seluruh tugas dan fungsi-fungsi dalam perusahaan. Tugas yang begitu banyak membuat general manager tidak memiliki banyak waktu untuk fokus memperhatikan berita-berita yang diterbitkan, sehingga berita-berita yang disebarkan tidak semuanya dipantau oleh general manager.

\section{Upaya yang dilakukan Editor dan General Manager Metrojambi.com dalam Mengatasi Kesalahan Penggunaan Bahasa dalam Penulisan Berita Metrojambi.com}

Banyaknya media massa yang ada provinsi jambi, menjadi salah satu kendala yang mengharuskan setiap media menyebarkan informasi secepat mungkin, karena keterlambatan penyebaran informasi akan membuat pembaca bagi media tersebut bisa berkurang. Namun, selain melakukan penyebaran secepat mungkin, setiap media juga harus memperhatikan setiap kesalahan yang terjadi pada berita yang di sebarkan dan melakukan perbaikan atau perubahan yang lebih baik selanjutnya.

Begitupun pada media massa metrojambi.com yang hadir menjadi media daring untuk mengembangkan metro jambi dan menerima tantangan zaman. Begitu banyak upaya yang dilakukan metrojambi.com untuk mengatasi kesalahan penulisan berita, salah satunya dengan lebih teliti lagi dalam mengecek tulisan sebelum berita di sebarluaskan, serta memberikan pelatihan-pelatihan pada wartawan maupun karyawan

${ }^{40}$ Herri Novealdi, Kendala Yang Dihadapi Ediotr, 11 Februari 2020

${ }^{41}$ Ikbal Ferdiyal, Kendala yang dihadapi editor, wawancara pada 11 februari 2020 
untuk meningkatkan kinerja yang lebih baik lagi. Untuk memperoleh kinerja yang lebih baik, tidak sekedar memberikan pelatihan-pelatihan pada wartawan maupun para karyawan, tetapi harus menjelaskan bahwa bahasa jurnalistik sangat penting bagi media massa, karena bahasa jurnalistik mampu membuat media massa diakui atau tidak eksistensinya.

Bahasa jurnalistik yang baik dan benar adalaha bahasa jurnalistik yang berpedoman pada bahasa Indonesia. setiap wartawan harus memahami ejaan yang berlaku dalam bahasa Indonesia. karena setiap berita yang menggunakan tulisan, baik itu cetak maupun online, para pembaca akan sangat memperhatikan setiap tulisan/ teks yang terkandung didalam berita tersebut. Melihat kesalahan penulisan yang banyak terjadi, Ikbal Ferdiyal selaku editor sekaligus menjabat sebagai pimpinan redaksi mengatakan bahwa ada beberapa pembaca yang berkomentar mengenai kesalahan dalam penulisan, yang menandakan pembaca merasa tidak nyaman dengan kesalahan tersebut. Demi memberikan pelayanan dan kenyamanan pembaca,dia mengatakan akan lebih teliti dalam mengecek setiap tulisan sebelum diterbitkan.

PUEBI diterapkan tidak saja pada media cetak, tetapi juga pada media online. PUEBI mengatur pemakaian huruf, penulisan kata, tanda baca dan penulisan unsur serapan. ${ }^{42}$

\section{Pemakaian Huruf}

a. Huruf kapital

1. Huruf Kapital dipakai sebagai huruf pertama awal kalimat. Misalnya: Kegiatan tersebut merupakan agenda tahunan

2. Huruf kapital di pakaian sebagai huruf pertama unsur nama orang, termasuk julukan. Misalnya: Gubernur Jambi Dr. Drs Fachrori Umar, M. Hum

3. Huruf kapital tidak dipakai sebagai hruruf pertama nama orang yang merupakan nama jenis atau suatu ukuran. Misalnya: ikan laga, 10 ampere, 20 volt

4. Huruf kapital tidak dipakai untuk menuliskan huruf pertama kata yang bermakna "anak dari" seperti bin, binti, boru, dan van, atau huruf pertama

${ }^{42}$ Suherli Kusmana dkk, Cerdas Berbahasa: Bahasa Indonesia untuk Perburuan Tinggi, ( Jakarta: Sarwiji Suwandi, 2018) h. 26 
kata tugas. Misalnya: Fitri binti Beddu Aming, Aziz bin Salim, Sinta boru sitanggang, Samuel andrian van Ophuijsen

5. Huruf kapital dipakai pada awal kalimat atau petikan langsung. Misalnya: "Pramuka cerdas melalui media digital di era milenial".

6. Huruf kapital dipakai sebagai huruf pertama setiap kata nama agama, kitab suci, dan Tuhan, termasuk sebutan dan kata ganti untuk Tuhan. Misalnya: Allah, Islam, Alquran, Tuhan, Alkitab, Hindu, Kristen, Budha, dll.

7. Huruf kapital dipakai sebagai huruf pertama unsur nama gelar kehormatan, keturunan, keagamaan, atau akademik yang diikuti nama orang, termasuk gelar akademik yang mengkuti nama orang. misalnya: Sutan Imam Husain, Haji Beddu, Doktor Subhan, Nabi Muhammad, dll.

8. Huruf kapital dipakai sebagai huruf pertama unsur nama gelar kehormatan, keturunan, keagamaan, profesi, serta nama jabatan dan kepangkatan yang dipakai sebagai sapaan. Misalnya: selamat datang Ustad, Terimakasih Dokter, dll.

9. Huruf kapital dipakai sebagai huruf pertama unsur nama jabatan dan pangkat yang diikuti nama orang atau yang dipakai sebagai pengganti nama orang tertentu, nama instansi, atau nama tempat. Misalnya: Wakil Presiden Kiyai Haji Mahruf Amin, Gubernur Jambi, Sekretasi Jenderal Kementrian, dll.

10. Huruf kapital dipakai sebagai huruf pertama nama bangsa, suku bangsa, dan bahasa. Misalnya: bangsa Indonesia, suku Bugis, bahasa Jawa. Namun nama bangsa, suku bangsa, dan kata keturunan tidak ditulis dengan huruf awal kapital. Misalnya: pengindonesiaan kata asing, inggris-inggrisan, dll

11. Huruf kapital dipakai sebagai huruf pertama nama tuhan, bulan, hari, dan hari besar atau hari raya. Misalnya: tahun baru Hijriah, bulan Februari, hari raya Idul Fitri, hari Natal, dll

12. Huruf kapital dipakai sebagai huruf pertama unsur nama peristiwa sejarah. Contoh: Perang Dunia II, Proklamasi Kemerdekaan Indonesia, dll. Huruf pertama peristiwa sejarah yang tidak dipakai sebagai nama, tidak ditulis denga $\mathrm{n}$ huruf kapital. Misalnya:Soekarno dan Hatta memproklamasikan kemerdekaan bangsa Indonesia, dll. 
13. Huruf kapital dipakai sebagai huruf pertama nama geografi. Misalnya: Jakarta, Jambi, Amerika Serikat, dll. Huruf pertama nama geografi yang bukan nama diri dan nama jenis tidak ditulis dengan huruf kapital. Misalnya: (nama diri) menyeberangi selat berenang di danau, (nama jenis) jeruk bali dll. Nama yang disertai nama geografi dan merupakan nama jenis, dapat dikontraskan atau disejajarkan dengan nama jenis lalin dalam kelompoknya. Misalnya: saya mengenal berbagai macam nama gula, seperti gula jawa, gula pasir, gula tebu, dan gula aren. Berikut bukan nama jenis, misalnya: Dia mengoleksi batik Jambi, dan batik Pekalongan. PUEBI 2015 menambahkan $\mathrm{c}$ ara pembedaan unsur nama geografi yang menjadi bagian nama diri (Proper Name) dan nama jenis (Common Name).

14. Huruf kapital dipakai sebagai huruf pertama semua kata (termasuk semua unsur bentuk ulang sempurna) dalam nama negeri, lembaga, badan, organisasi atau dokumen, kecuali kata tugas, seperti di, ke, dari, dan, yang, dan untuk. Misalnya: Republik Indonesia, Peraturan Presiden Republik Indoesia Nomor 4 Tahun 2010.

15. Huruf kapital dipakai sebagai huruf pertama setiap kata (termasuk unsur kata ulang sempurna) di dalam judul buku, majalah, surat kabar, kecuali kata tugas yang tidak terletak pada posisi awal. Misalnya: Saya membaca surat kabar yang berjudul "Dirawat di RSUD Raden Mattaher, Noval Pengidam Gizi Buruk Butuh Bantuan Pengobatan".

16. Huruf kapital dipakai sebagai huruf pertama unsur singkatan nama gelar, pengkat, atau sapaan. Misalnya: S.H (sarjana hukum), S.Kom. (sarjana komunikasi), Daeng, Datuk, dll.

17. Huruf pertama sebagai huruf kata penunjuk hubungan kekerabatan. Misalnya: " kapan Bapak pulang” Tanya dina. Istilah kekerabatan berikut bukan merupakan penyapaan atau pengacuan. Misalnya: kita harus menyayangi bapak dan ibu kita. Kata ganti Anda ditulis dengan huruf awal kapital. Misalnya: sudahkah Anda tahu?

b. Huruf Miring

1) Huruf miring dipakai untuk menuliskan judul buku, nama majalah, atau nama surat kabar yang dikutip dalam tulisan, termasuk dalam daftar 
pustaka. Misalnya: Haris Sumadiria, Jurnalistik Indonesia, menulis berita dan feature panduan praktis jurnalis professional (Bandung: Simbiosa Rekatama Media, 2005), 59-61

2) Huruf miring dipakai untuk menegaskan atau mengkhususkan huruf, bagian kata, kata, atau kelompok kata dalam kalimat. Misalnya: Dalam Bab ini tidak dibahas pemakaian tanda baca, dll.

3) Huruf miring digunakan untuk menuliskan kata yang menggunakan bahasa daerah atau bahasa asing. Misalnya: Assessment. Ada beberapa yang menjadi catatan dalam PUEBI sebagai berikut:

a. Nama diri seperti nama orang, nama lembaga, nama organisasi

b. Dalam naskah tulisan tangan atau mesin ketik, bagian yang seharusnya di cetak miring cukup di garis bawah.

c. Kalimat atau teks berbahasa asing atau berbahasa daerah yang dikutip secara langsung dalam teks berbahasa Indonesia ditulis dengan huruf miring. Catatan PUEBI 015 menggunakan frasa bahasa daerah atau bahasa asing, sedangkan pedoman ejaan sebelumnya memakai frasa bukan bahasa Indonesia.

2. Penulisan Kata

a. Kata Berimbuhan

1. Imbuhan (awalan, sisipan, akhiran, serta gabungan awalan dan akhiran) ditulis serangkai dengan bentuk dasarnya. Misalnya: mempermudah, perbaikan, kemauan. Imbuhan yang diserap dari unsur asing, seperti isme, man, -wan, atau -wi, ditulis serangkai dengan bentuk dasarnya. Misalnya: seniman, kamerawan, gerejawi, sukuisme.

2. Bentuk terikat ditulis serangkai dengan kata yang mengikutinya. Misalnya: paripurna, prasejarah, subbagian, tritunggal, tunakarya,biokimia, adibusana, aerodinamika, dll. Catatan:

a. Bentuk terikat yang diikuti oleh kata yang berhuruf awal kapital atau singkatan yang beurpa huruf kapital dirangkaikan dengan tanda hubung (-). Misalnya: non-Indonesia, non-ASEAN, anti-PKI, dll.

b. Bentuk maha yang diikuti kata turunan yang mengacu pada nama atau sifat Tuhan ditulis terpisah dengan huruf awal kapital. 
Misalnya:Meningkatkan rasa syukur kepada Tuhan yang Maha Pengasih.

c. Bentuk maha yang diikuti kata dasar yang mengacu kepada nama atau sifat Tuhan, kecuali kata esa, ditulis serangkai Misalnya: Tuhan Yang Mahakuasa yang akan menentukan arah hidup kita, kepada Allah Tuhan Yang Maha Esa, dll.

b. Bentuk Ulang

1) Bentuk ulang ditulis dengan menggunakan tanda hubung (-) di antara unsurunsurnya.

Contoh:
a) Anak-anak
b) Biri-biri
c) Lauk-pauk
d) Berjalan-jalan
e) Ubur-ubur
f) Cumi-cumi
g) Kupi-kupi
h) Sayur-mayur dll.

2) Bentuk ulang gabungan kata ditulis dengan mengulang unsur pertama. Contoh:
a) Surat kabar, berasal dari kata surat-surat kabar
b) Kapal barang, berasal dari kata kapal-kapal barang
c) Rak buku, berasal dari kata rak-rak buku, dll

3) Bila bentuk ulang diberi huruf kapital, misalnya nama diri atau judul buku, majalah, dll, bentuk ulang sempurna diberi huruf capital pada huruf pertama tiap unsurnya, sedangkan bentuk ulang yang lain hanya diberi huruf capital pada huruf pertama unsur pertamanya.

Contoh:
a) Ia diberikan tugas makalah yang berjudul "Penerapan Asas-Asas Hukum Perdata".
b) Ayah pernah berkata "Terus-menerus Ramah-tamah" adalah kunci keberhasilan. 
c. Gabungan Kata

1) Unsur gabungan kata yang lazim disebut kata majemuk, termasuk istilah khusus, ditulis terpisah.

contoh: Duta bahasa, Kambing hitam, Rumah sakit jiwa, dll.

2) Gabungan kata yang dapat menimbulkan salah pengertian ditulis dengan membubuhkan tanda hubung (-) diantara unsur-unsurnya.

Contoh: Bertemu langsung fachrori (bertemu langsung dengan fachrori)

3) Gabungan kata yang penulisannya terpisah tetap ditulis terpisah jika mendapat awalan atau akhiran.

Contoh: garis bawahi

4) Gabungan kata yang mendapatk awalan dan akhiran sekaligus ditulis serangkai.

Contoh: dilipatgandakan, menggarisbahwahi, dll.

5) Gabungan kata yang sudah padu ditulis serangkai.

Contoh:apalagi, beasiswa,kilometer, dll.

c. Kata Depan

Kata depan (di, ke, dan dari), ditulis terpisah dari kata yang mengikutinya.

Contohnya: di antara para karyawan.

d. Partikel

1) Partikel (-lah, -kah, dan -tah) ditulis serangkai dengan kata yang mendahuluinya.

Contoh: bacalah, apakah, siapakah.

2) Partikel (pun) ditulis terpisah dari kata yang mendahuluinya, tatpi jika merupakan kata penghubung, maka harus ditulis serangkai.

Contoh: apa pun, siapa pun, meskipun, walaupun, dll.

3) Partikel (per) yang berarti (demi, tiap, mulai) ditulis terpisah.

Contoh: satu per satu, per orang, dII. ${ }^{43}$

Setiap wartawan harus mampu memahami arau menguasai PUEBI agar mampu menulis berita dengan baik, percuman jika setiap ada pelatihan dan pembinaan dalam liputan maupun tulisan, para wartawan terus diikutsertakan dalam hal tersebut, tetapi tidak memahami ada yang di sampaikan atau ilmu yang berikan pada saat pelatihan.

${ }^{43}$ Aplikasi PUEBI di android 
General manger/ penanggung jawab, Herri Novealdi mengatakan bahwa setiap wartawan sebelum melakukan terjun kelapangan untuk melakukan liputan atau melakukan proses pencarian informasi akan diberikan pelatihan terlebih dahulu beberapa waktu hingga dinyatakan layak untuk terjun lapangan.

Tak sedikit yang dilakukan Editor dan General Manager untuk memberikan yang terbaik demi menjadi media massa terbaik di provinsi khususnya serta memberikan kenyamanan bagi para pembaca dalam memperoleh informasi.

Namun tak mampu di pungkiri, hal tersebut masih memiliki kekurangan yang harus di perbaiki, hingga Editor dan General Manager melakukan pengecekan yang lebih ketat sebelum berita di sebarkan.

Setiap wartawan harus mengerti bahasa jurnalistik, agar mampu menanggulangin kesalahan bahasa yang banyak terjadi, serta memahami kaidah bahasa jurnalistik dan bahasa indonesia.

\section{E. Penutup}

Bahasa jurnalistik merupakan bahasa pers yaitu bahasa yang digunakan di media massa. Bahasa jurnalistik masih berpedoman pada bahasa Indonesia yang baik dan benar, yang sesuai dengan KBBI/ PUEBI. Hasil penelitian dapat disimpulkan bahwa metrojambi.com merupakan media massa berbasis online yang berawal dari media massa berbasis cetak yang diberinama Metro Jambi (Koran Harian Metro Jambi). Kehadiran metrojambi.com selain untuk meningkatkan Koran Harian Metro Jambi, juga demi menerima tantangan zaman. Penggunaan bahasa jurnalistik pada penulisan berita metrojambi.com masih belum sempurna, masih terdapat beberapa kesalahan dalam penulisan, seperti kesalahan ejaan (EYD/KBBI), kalimat/ kata yang tidak padat, kalimat/ kata yang kurang jelas, kalimat/ kata yang tidak sederhana, tidak menarik, tidak lugas serta masih terdapat beberapa pemborosan kata. Hal ini juga mengakibatkan beberapa pembaca sempat berkomentar mengenai kesalahan tersebut.

Kendala yang dihadapi dalam penerapan bahasa jurnalistik yaitu waktu dan tekanan. Waktu menjadi kendala yang sangat kuat, keterlambatan dalam mempublikasikan berita dapat mengakibatkan berkurangnya pembaca pada media tersebut, karena pembaca telah membaca berita tersebut pada medialain, sehingga pembaca telah mengetahui informasi tersebut. Tekanan juga merupakan hal yang 
menjadi kendala dalam penerapan bahasa jurnalistik, karena tekanan yang dialami oleh editor dalam mengedit tulisan wartawan yang kurang rapi akan membutuhkan waktu yang lama, sedangkan persaingan media online juga berada pada kecepatan dalam mempublikasikan berita, sehingga ketelitian dalam penulisan sering terabaikan. Demi mengatasi kesalahan-kesalahan tersebut, para wartawan maupun karyawan diberikan/ diikuti pelatihan yang berhubungan dengan peliputan dan penulisan berita. Selain itu, editor metrojambi.com akan lebih teliti lagi dalam mengecek tulisan yang akan disebarkan atau dipublikasikan. Setiap editor dan general manager selalu berupaya meminimalisirkan kesalahan dengan berbagai cara, meskipun mereka harus berkejarkejaran dengan waktu, karena bagi editor, waktu dapat menentukan banyak atau tidaknya pembaca pada media, serta bahasa mampu membuat media diakui eksistensinya.

\section{Daftar Pustaka}

Asep Syamsul, M Romli. Jurnalistik Online: Panduan Mengelola Media Online. Nuansa: Bandung. 2012

Chaer, Abdul. Bahasa Jurnalistik. Jakarta: PT. Rineka Cipta, 2010

Iskandar, Maskun dan Atmakusumah. Panduan Jurnalistik Praktis, Mendalami Penulisan

Berita dan Feature, Memahami Etika dan Hukum Pers, Cetakan Kelima. Jakarta:

Lembaga Pers Dr. Soetomo (LPDS), 2012

M Romli, Asep Syamsul. Jurnalistik Online: Panduan Mengelola Media Online. Nuansa:

Bandung, 2012

M. Romli Asep Syamsul. Jurnalistik Online. Bandung: Nuansa Cendikia, 2014

Setiati, Eni. Ragam Jurnalistik Baru dalam Pemberitaan. Strategi Wartawan Menghadapi

Tugas Jurnalistik. Yogyakarta: CV ANDI OFFSET (AND), 2005

Sumadiria Haris, Jurnalistik Indonesia: Menulis Berita dan Feature Panduan Praktis Jurnalis Profesional (Bandung: Simbiosa Rekatama Media, 2005

Sumadiria Haris. Bahasa Jurnalistik: Panduan Praktis Penulis dan Jurnalis. Bandung: Simbiosa Rekatama Media, 2006

Sumadiria, Haris. Jurnalistik Indonesia Menulis Berita dan Ferature Cetakan Keempat. Bandung: Simbiosa Rekatama Media, 2011 
Amiluddin. “Analisis Bahasa Jurnalistik Berita Utama Harian Berita Kota

Ghaniy, Rasyiid. Kesesuaian Penulisan Berita Tribun Online Jambi dengan Bahasa Jurnalistik. Skripsi. Fakultas Ushuluddin: Universitas Islam Negeri, 2017

Hatika, Mutiara. "Strategi Pemberitaan (LKBN) Antara Biro RIAU Dalam Menghadapi Persaingan Dengan Media Online" JOM FISIP Vol. 5 No. 1 - April 2018

Khairunnisa, Eneng. "Penerapan Bahasa Jurnalistik Pada Berita Utama "Straight News" Di Surat Kabar "Radar Bekasi" Edisi 1-5 Oktober 2012". Skripsi. Jakarta: Universitas Islam Negeri Syarif Hidayatullah, 2013

Rachmat dan Kriyanto. Metodologi Riset, Komunikasi Disertai Contoh Praktisi Riset Media, Publik Relatio, Advertising, Komunikasi Organisasi, Komunikasi Pemasaran. Jakarta: Kencana Predana Media Group, 2006

Makassar (Edisi September 2017)". Skripsi. Makassar: Universitas Islam Negeri Alauddin Makassar, 2018

Yanuar Nugroho et. Al,. Memetakan Lansekap Industri Media Kontemporer di Indonesia. Jakarta: Centre for Innovation Policy and Governance, 2012

Jambi, Metro. "Menu Metrojambi.com; kategori berita". diakses melalui https://metrojambi.com, tanggal 12 februari 2020

Jambi, Metro. "Tentang Kami", diakses melalui alamat

https://https://https://metroJambi.com/profil/tentang-kami/profil/tentangkami/profil/tentang-kami, tanggal 12 Desember 2019

Siska Pratiwi, Ni Wayan eviyanti. "Kemampuan Siswa Kelas VII B SMP Negeri 1 Torue dalam Menulis Teks Berita", diakses melalui alamat http://jurnal.untad.ac.id/jurnal/index.php/BDS/article/viewFile/10528/8287, tanggal 16 desember 2019

Supit, Gracia Ilma dkk. "Analisis Penerapan Bahasa Jurnalistik Berita Kriminal Pada Koran Tribun Manado". diakses melalui alamat https://www.google.com/url?sa=t\&source=web\&rct=i\&url=https://ejournal.unsra t.ac.id/index.php/actadiurnakomunikasi/article/download/20983/20670\&ved=2a hUKEwjWwODNsu7mAhXRbCsKHXs9AGUQFYCp88BX7 Vfd, tanggal 6 Januari 2020 